\title{
Co-infection with malaria and HIV in injecting drug users in Brazil: a new challenge to public health?
}

\author{
FRANCISCO INÁCIO BASTOS, ${ }^{1}$ CHRISTOVAM BARCELLOS, ${ }^{1}$ \\ CATHERINE M. LOWNDES ${ }^{2}$ \& SAMUEL R. FRIEDMAN ${ }^{3}$
}

\author{
${ }^{1}$ Department of Health Information (DID/CICT), Oswaldo Cruz Foundation (FIOCRUZ), \\ UNAIDS Collaborating Centre, Rio de Faneiro, Brazil, ${ }^{2}$ Department of Social and \\ Preventive Medicine, Laval University, Québec, Canada $\mathcal{E}^{3}{ }^{3}$ National Development and \\ Research Institutes, Inc., New York City, NY, USA
}

\begin{abstract}
Aims. To describe AIDS and malaria geography in Brazil, highlighting the role of injecting drug users (IDUs) in malaria outbreaks occurring in malaria-free regions, and the potential clinical and public health implications of malaria/HIV co-infection. Design. Review of the available literature and original analyses using geoprocessing and spatial analysis techniques. Findings. Both HIVIAIDS and malaria distribution are currently undergoing profound changes in Brazil, with mutual expansion to intersecting geographical regions and social networks. Very recent reports describe the first clinical case of AIDS in a remote Amazonian ethnic group, as well as malaria cases in Rio de faneiro state (hitherto a malaria-free area for 20 years); in addition, two outbreaks of both infections occurred at the beginning of the $1990 \mathrm{~s}$ in the most industrialized Brazilian state (São Paulo), due to the sharing of needles and syringes by drug users. Spatial data point to: (a) the expansion of HIVIAIDS towards malarigenic areas located in the centre-west and north of Brazil, along the main cocaine trafficking routes, with IDU networks apparently playing a core role; and (b) the possibility of new outbreaks of secondary malaria in urban settings where HIV/AIDS is still expanding, through the sharing of needles and syringes. Conclusions. New outbreaks of cases of HIV and malaria are likely to occur among Brazilian IDUs, and might conceivably contribute to the development of treatment-resistant strains of malaria in this population. Health professionals should be alert to this possibility, which could also eventually occur in IDU networks in developed countries.
\end{abstract}

\section{Introduction}

Due to unsafe injecting practices and dispossessed living conditions, injecting drug users (IDUs) are frequently affected by many different infectious diseases. Besides those most fre- quently studied, e.g. HIV/AIDS and hepatitis, ${ }^{1}$ concern is currently growing with respect to other emerging and re-emerging infectious diseases prevalent among IDUs, ${ }^{2}$ including tetanus, $^{3}$ visceral leishmaniasis ${ }^{4}$ and malaria. ${ }^{2,5}$

Correspondence to: Francisco Inácio Bastos, Fundação Oswaldo Cruz, Av. Brasil 4365, Biblioteca de Manguinhos, Room 209, Manguinhos 21045-900, Rio de Janeiro, Brazil. Fax: (0055) (21) 260 6707/290 1696; e-mail: Bastos@Fiocruz.br

Submitted 13th August 1998; initial review completed 15th January 1999; final version accepted 12th February 1999. 
This is particularly the case in countries such as Brazil, where the size and diversity of the country, as well as poverty, social inequality and unequal development (including industrialization and urbanization) have produced a complex epidemiological transition, with the simultaneous occurrence of high rates of 'modern' diseases (e.g. HIV, cancer, heart disease) ${ }^{6}$ and 'traditional' tropical diseases (e.g. malaria, leishmaniasis, Chagas' disease), ${ }^{7}$ in addition to high levels of mortality secondary to violence and consumption of psychoactive drugs. ${ }^{8}$

In the present paper we review data from a number of different sources, including geographical/ecological analyses of the AIDS epidemic ${ }^{9-14}$ as well as individual and multi-centre field studies on IDUs, ${ }^{15-17}$ on: (a) recent trends in the HIV/AIDS epidemic, with particular reference to IDUs; (b) malaria distribution and occurrence in Brazil, including recent outbreaks of secondary malaria in IDUs in the industrialized southeast of the country, through the sharing of injecting equipment; (c) the risk of double infection with HIV-1 and malaria through the sharing of needles and syringes, and possible scenarios for diffusion of malaria and HIV-1 co-infection through networks of IDUs in Brazil; and (d) the possible (re)emergence of resistant malaria strains among IDUs. The main purpose of the present paper is to draw attention to the existence and implications of a potentially serious emerging public health challenge, namely the transmission of malaria infection among IDUs via sharing of injection drug equipment, and co-infection with malaria and HIV in IDUs. Some implications of the tendencies discussed below for prevention and treatment strategies to be developed among IDUs. Their networks are also explored.

\section{Methods}

The present paper includes a review of published papers on malaria infection in Brazil, mainly concerning the spatial distribution of the disease, as well as epidemiological and socio-demographic studies. Analyses of AIDS geography in Brazil presented here review both former analyses performed by the authors as well as presenting new analyses and an original map on AIDS and malaria geography in Brazil.

We reviewed standard medical and social science databases (e.g. Medline), as well as addi- tional databases targeting literature available only in Portuguese or Spanish (e.g. Lilacs). Abstract books and/or electronic databases (CDROMs) from recent major conferences (e.g. 12th International Conference on AIDS; 9th International Conference on the Reduction of Drug Related Harm) were examined thoroughly. The available international and regional major conferences proceedings on tropical medicine and related areas highlighting malaria in South America were also assessed.

Analyses were carried out using data from the National Division of STD/AIDS (Brazilian Ministry of Health) and the Brazilian Institute of Geography and Statistics (FIBGE), which were merged and geo-referenced using the spatial coordinates of the cities included in the worksheet. The major Brazilian highways were digitalized by the authors, using a digitizer table and geoprocessing software (Mapinfo 4.0).

\section{The social geography of AIDS in Brazil}

As of February 1998 over 128000 AIDS cases had been officially registered in Brazil, roughly $21 \%$ of them among IDUs. ${ }^{18}$ Initially concentrated in the two main cities (São Paulo and Rio de Janeiro, both situated in the wealthiest southeast region), the AIDS epidemic in Brazil subsequently underwent a major diffusion during the late 1980 s and early 1990s, spreading through three main axes: north-west (including the Amazon rain forest), south and, to a lesser extent, north-east. Former geographic analyses show that the gravimetric centres of AIDS (spatial mean of reported AIDS cases, calculated for each year between 1984 and 1993) have moved north-west, suggesting that more AIDS cases are being registered in northern and centre-west regions of the country. ${ }^{9}$ More recent analyses, employing both spatial analysis techniques ${ }^{11}$ and descriptive statistics of Brazilian AIDS subepidemics, ${ }^{14}$ confirm these trends and also indicate a more recent intense diffusion of the AIDS epidemic towards the south coast.

Substantial increases have occurred in the contribution of drug injection to AIDS cases in Brazil. The proportion of IDUs as an HIV exposure category increased from approximately $4 \%$ at the beginning of the epidemic to approximately $25 \%$ currently. AIDS cases in IDUs have been reported from all Brazilian states except Acre (northern region-Amazon Forest). 
Figure 1 shows the cumulative number of AIDS cases in Brazilian micro-regions in recent years. The state of São Paulo concentrates over $50 \%$ of all AIDS cases and over $75 \%$ of cases registered among IDUs. ${ }^{12,14}$ The majority of cases among IDUs occur along a 'strip' crossing São Paulo state, connecting the centre-west (the region where primary malaria foci are located) and the coast (mainly in Santos-the largest port in South America-and surrounding areas). ${ }^{10}$ This strip is coincident with the main cocaine trafficking routes ${ }^{19}$ within and through Brazil and enables contact between drug smugglers, drivers involved in drug transportation and drug users living and/or moving across the stripe.

In comparison to cases in other exposure categories, AIDS cases among IDUs are also more concentrated in the lower income strata of the population. ${ }^{20,21}$ IDUs with AIDS are thus more exposed to diseases prevalent among the poor and underserved, such as tuberculosis. ${ }^{20}$ This fact has been clearly demonstrated in São Paulo, where both the AIDS epidemic and tuberculosis are spreading at a faster rate in the poorest peripheral areas which surround the richest central areas ${ }^{21}$ of the city. In accordance with this, a large number of IDUs interviewed in studies in Rio de Janeiro, ${ }^{22,23}$ Santos (São Paulo state) ${ }^{16}$ and Salvador, Bahia (North-East Brazil) ${ }^{24}$ suffered from multiple co-infections together with HIV infections, including viral hepatitis (HBV, $\mathrm{HCV}$ and hepatitis $\mathrm{G}$ virus-HGV/GBV-C), other retroviral infections (HTLV-I/II) and tuberculosis.

The extent to which IDUs are a mobile population has become clear from research conducted in response to AIDS. ${ }^{25-27}$ In Brazil, studies carried out on $\mathrm{IDUS}^{28}$ show a pattern of recurrent movement among different settings, including Rio de Janeiro, Santos and cities situated on the borders of Brazil with coca/cocaine-producing countries, e.g. in the state of Mato Grosso (centre-west).

Evidence suggests that IDUs are an extremely important factor in the spread of the HIV epidemic in Brazil, both in terms of forming a bridge between the IDU population and the general population through heterosexual transmission and in terms of geographical spread of the epidemic. ${ }^{10,13,29}$ Ecological evidence indicates that the HIV epidemic in Brazil has proceeded in waves, spreading outwards from large to medium-sized and small cities, the first wave being composed of gay men and/or IDUs, and shortly afterwards a wave of heterosexuals (non-IDUs), principally women. ${ }^{11}$

The social geography of malaria in contemporary Brazil

Primary malaria infection in contemporary Brazil is largely restricted to the north and centre-west regions of the country, although other spots of primary foci occur in states of the north-east region of the country such as Bahia. ${ }^{30}$ Despite intensive malaria eradication programmes in the 1970 s the main malaria foci, which are situated in and around the Amazon rain forest, remain active and have even broadened their limits, with increases in the number of new infections registered in recent years. ${ }^{31,32}$ Figure 1 indicates the main malaria endemic region (shaded area). Primary foci of malaria are concentrated in the southern Amazon region, where intensive ecological and demographic changes are currently taking place, due in part to large movements of migrants towards gold mining activities. ${ }^{33}$

Demographic analyses indicate that during the 1980 s and early 1990 s the traditional Brazilian internal migration trend-from the north-east to the large cities of São Paulo and Rio de Janeiro in the south-east - was largely surpassed by new migration streams from the south of the country towards the new expansion frontiers in the north and centre-west. This seems to be due to the economic crisis in the industrialized south-east during the 1980 s, as well as to the opening up of alternative opportunities in mining and agroindustrial settlements far from the traditional developed centres. ${ }^{34}$ As an example of this, one of the states situated in the Amazon forestRondonia-doubled its population between 1981 and 1985 (from 491000 to 1040000 inhabitants).

The population increases in these 'new' migration regions have occurred selectively, in the sense that they have involved primarily migration of young males to mining and ranching settlements. Most migrants have temporary (seasonal) employment, and thus a permanent social infrastructure in these areas is a rare phenomenon, with a substantial part of this population remaining socially and spatially mobile.

Several studies have shown very high levels of malaria infection in Amazonian migration areas. $^{31,33}$ These economic expansion frontiers 


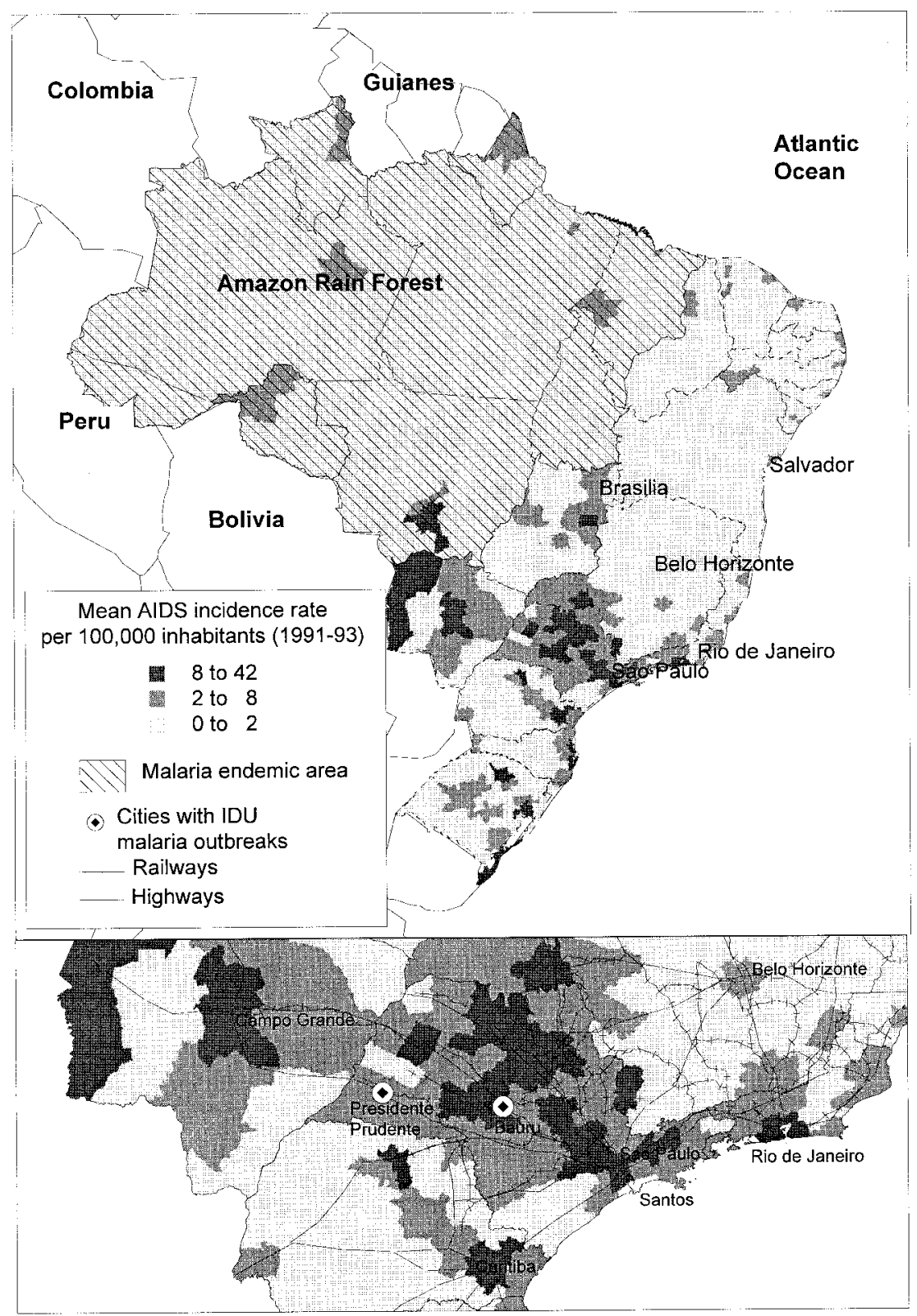

Figure 1. Map of malaria and AIDS distribution in Brazil. Mean AIDS incidence rate per 100 000 inhabitants (1991-93) is displayed aggregated in micro-regions, forming a grey scale from low incidence (light) to high incidence (dark) regions. Dark areas are located mainly along railways and highways. The malaria endemic area is shaded, covering the northern Amazon region. Cities where malaria outbreaks have been observed are indicated by black circles in the detailed map.

concentrate demographic, environmental and cultural risk factors for malaria. First, deforestation promotes both a shift in vector (anophe- line mosquito) feeding habits (from animals to humans), as well as increasing the mosquito population by eliminating its natural enemies. ${ }^{35}$ 
Table 1. Secondary malaria outbreaks (or cases) among IDUs in the State of São Paulo-co-infection with HIV, 1988-90

\begin{tabular}{|c|c|c|c|c|}
\hline $\begin{array}{l}\text { Cities (São Paulo } \\
\text { State) }\end{array}$ & Year & $\begin{array}{c}\text { Infectious } \\
\text { agent }\end{array}$ & $\begin{array}{c}\text { No. of malaria } \\
\text { cases } \\
\text { assessed }\end{array}$ & $\begin{array}{c}\text { Percentage infected } \\
\text { with HIV }\end{array}$ \\
\hline São Paulo ${ }^{44}$ & $1988 / 9$ & P. vivax & 2 & Unavailable \\
\hline P. Prudente ${ }^{43}$ & $1988 / 9$ & P. vivax & 9 & $5 / 6(83 \%)$ \\
\hline Bauru ${ }^{44,45}$ & 1990 & P. vivax & 119 & $53 / 91(58 \%)$ \\
\hline
\end{tabular}

Sources: Reference numbers quoted in the table (cities).

Secondly, these migrants in Brazil are selectively poor, with low schooling levels, and tend to live in remote, temporary shelters in areas with poor sanitation ${ }^{30}$ and frequent lack of access to health care. $^{32,36}$

In recent years a very high geographical turnover of Brazilian migrants has been observed, with circular contact between frontier migrants and their places of origin. This poses a threat to areas where malaria has been eradicated or brought under control. ${ }^{32}$ In some malaria-free areas potential vectors remain, with concomitant risk of resumption of the original malaria transmission cycle. In addition to primary malaria transmission in areas where endemic vector populations still exist the disease can also be transmitted parenterally.

For example, in Rio de Janeiro state (southeastern region), autochthonous cases of malaria have not been observed for several decades. On the other hand, exogenous cases of malaria continue to occur, principally in males $(92 \%)$ of young age (almost entirely in the age group 20-39 years), more than $50 \%$ of whom are exgold miners and more than $80 \%$ of whom come from areas where malaria is endemic (the Amazon region and parts of the centre-west). Since the disease is rare in Rio de Janeiro diagnosis is often delayed, leading to an increased transmission potential from the infected person as well as to higher morbidity and sometimes even death. $^{37}$

In May 1997 three cases of Plasmodium vivax malaria were detected in Rio de Janeiro state. None of the three had been to a malaria-endemic area, none were IDUs and all three were infected in Itaipuaçu (a semi-rural, peri-urban, coastal area), where small foci of the mosquito vector (Anopheles) still exist. It took more than 1 month for the disease to be diagnosed correctly in these people. $^{37}$
While parenteral transmission of malaria via infected blood or blood products appears to be rare nowadays, ${ }^{38}$ of great concern are indications of the potential for secondary parenteral transmission of malaria in Brazil through the sharing of drug-injecting equipment. Transmission of malaria infectious agents through needle and syringe sharing was first observed in Egypt, ${ }^{39}$ and thereafter in US states such as Illinois ${ }^{40}$ and California. ${ }^{41}$ There is also evidence that the mixing of quinine with heroin, observed commonly, in the contemporary drug scene, ${ }^{42}$ was first introduced by Chicago drug dealers in the $1940 \mathrm{~s}$ in order to halt an outbreak of malaria among IDUs that took place in the winter. ${ }^{40}$

Two outbreaks of secondary malaria have been documented recently among IDUs in São Paulo state ${ }^{43-45}$ (Table 1 and Fig. 1), where primary transmission by mosquitoes has not taken place since the end of the 1960 s except for small foci situated in the remnants of the Atlantic tropical forest. ${ }^{46}$ These two outbreaks occurred in cities that connect São Paulo state with the centre-west (Presidente Prudente) and the northern regions (Bauru) through highways and railways (detail of Figure 1). These cases were due to secondary parenteral transmission, since the mosquito vector is not found in these areas, and the cases of malaria identified were without exception in people who reported recent syringe/ needle-sharing. When questioned about their exposure, several infected people reported having injected drugs with 'a guy returning from the North/Centre-west'. ${ }^{43-45}$

These outbreaks demonstrate the potential for the parenteral spread of malaria via the sharing of drug injection equipment, and suggest that IDUs could act as a bridge in an eventual reurbanization of malaria in Brazil. In this context, the documented high mobility of IDUs (see above), in conjunction with the fact that they 
tend to be poor, have many infections, are frequently immunosuppressed and tend not to have access to adequate health services, suggests that malaria infection may, in many cases, pass unnoticed in IDUs thus increasing the risk of transmission from this population. Urban transmission of malaria in Brazil by IDUs returning/ undergoing circular contact from/with malaria foci areas in the Amazon forest and the centrewest and/or by migrants between migration frontiers and their places of origin is thus a serious concern.

As shown in the detail of Figure 1, the malaria outbreaks in São Paulo state occurred precisely in 'bridging areas', connecting 'modern' urban Brazil (with high rates of IDUs), and 'old' Brazil (with few drug users, but high rates of malaria). In addition, IDUs and migrants have similar socio-demographic characteristics, in the sense that both populations tend to be poor, male and young. Thus, taking the available data together from an ecological perspective, it seems likely that IDUs and migrants could have social networks in common, as seems to be the case in the aforementioned outbreaks. These social networks could link frontier migrants in circular contact between malaria-free south-east regions of the country and areas of malaria foci in the Amazon forest and the centre-west, and IDUs moving along the routes of cocaine trafficking through the centre-west/south-east axis of the country (see above).

\section{$H I V / m a l a r i a$ co-infection in IDUs}

In the two secondary malaria outbreaks in São Paulo detailed above, $83 \%$ (Presidente Prudente) and $58 \%$ (Bauru) of the IDUs with malaria were also infected with HIV (Table 1). These outbreaks therefore demonstrate the potential for malaria-HIV co-infection in IDUs in Brazil.

Further, as noted above, the AIDS epidemic in Brazil has spread toward the north and centrewest macro-regions-important sites of primary malaria foci-and very recently a first case of AIDS was detected in a native Brazilian tribe, located far from any town or village (in the Amazon forest border with Suriname) in a region where malaria is endemic. ${ }^{47}$

Most studies of co-infection with HIV and malaria have been carried out in the subSaharan region of Africa, where both infections are very prevalent. Drug injection has not in general been a common behaviour in this region so far, although recent reports ${ }^{48}$ point to a mutable scene of drug use in those countries, with a putative epidemiological impact in the foreseeable future.

The clinical relationship between the two infections remains controversial and a clear synergy, as in the case of tuberculosis/HIV coinfection, ${ }^{49}$ has not been observed although some authors point to higher recrudescence rates of $P$. falciparum and a longer fever clearance time among AIDS patients, ${ }^{50}$ as well as reduced humoral responses to malaria ${ }^{51}$ and poorer clinical prognosis, ${ }^{52}$ especially in advanced AIDS cases.

Bloland et al. ${ }^{53}$ describe an enhanced effect of both infections (HIV-1 and P. falciparum) on perinatal transmission of malaria, with increased post-neonatal mortality. This latter interaction seems to be the only consistent one in a recent review, ${ }^{54}$ although new studies employing HIV-1 RNA viral load measurements instead of CD4 counts may throw new light on this question. ${ }^{55}$

\section{Discussion}

Prospects for co-infection of HIV and malaria among IDUs, and for the emergence of resistant strains of malaria

Two key variables are correlated with the increase in the spread of malaria infection and the difficulties now frequently encountered both in prophylaxis and treatment of malaria in Brazil and elsewhere, namely delay in seeking treatment and the increasing prevalence of resistant malaria infections. First described in Brazil in 1910 by $\mathrm{Neiva}^{56}$ following the appearance of resistance of one malaria agent- $-P$. falciparumto quinine, malaria resistance to several prophylactic and treatment regimens is now reported world-wide. ${ }^{57}$

In addition, two essential factors in the development and spread of resistant strains of infectious agents are: (a) lack of specific immunity and/or decrease in non-specific immunity, both vital elements for the removal of the small fraction of parasites that remain in the blood stream after drug action; ${ }^{57}$ and (b) non-compliance of patients with treatment regimens. The main consequence of these factors is the interaction of apparently healthy carriers with the community (both discharged inpatients and outpatients under erratic therapeutic regimens), usually 
selectively infected with strains that resisted the incomplete treatment regimens. ${ }^{58}$

Frequently ill from several different infectious conditions, including fever due to AIDS, nonAIDS HIV-related conditions, tuberculosis, phlebitis or cutaneous abscesses, and probably unaware of the possibility of malarial infection (originating as they do mainly from non-malarigenic areas), many IDUs may lack the capacity to recognize the fever and malaise induced by malarial infection as a distinct entity, and so may not seek prompt treatment. IDUs in Brazil ${ }^{20,21}$ and elsewhere ${ }^{59}$ are disproportionately located among the poorest strata of society, and have low general levels of health and immunity, even in the absence of HIV infection. ${ }^{16,22,23}$

Thus, IDUs potentially concentrate the factors involved in the emergence and spread of resistant strains: treatment delay increases the reproductive rate of the pathogen as a consequence of non-elimination of gametocytaemia from carriers; immunosuppression, varying levels of which are commonly found in IDUs, may decrease the efficiency of removal of the fraction of parasites that remain in the bloodstream after drug action; furthermore, for various reasons such as social stigmatization/prejudice, inadequacy and insensitivity of medical personnel, poverty and homelessness, IDUs frequently do not comply with prophylactic and therapeutic regimens, and could thus be infected with strains that resist such incomplete regimens. ${ }^{60}$ It is worth noting here that the standard suppressive (prophylactic) regimen with chloroquine phosphate must be continued for 6 weeks after potential exposure and that some resistant strains of $P$. falciparum must be treated with quinine, ${ }^{57}$ a potent but rather toxic drug with unpleasant side-effects.

The above factors have been reported among IDUs in the case of other co-infections, e.g. tuberculosis, ${ }^{60}$ and will probably be involved in the cases of HIV-infected IDUs migrating to and from malarigenic areas. Importantly, noncompliance with treatment regimens was an important factor in the spread of resistant strains of tuberculosis in the United States, ${ }^{61,62}$ and was directly observed by Barata et al. ${ }^{45}$ in the outbreak of malaria among IDUs described above in São Paulo State.

Implications for prevention and treatment

Taken together, the data discussed in this paper indicate the potential for infection of IDUs with malaria and the consequent parenteral spread of this infection through sharing of drug-injecting equipment. Given that pockets of malaria vectors still exist in some urban areas in Brazil, the potential for a resurgence of primary malaria transmission also exists.

Given the very high levels of HIV infection documented in IDUs in Brazil, ${ }^{29}$ cases of coinfection with HIV and malaria are likely to occur in this situation, with potential interactive effects (described above). In addition, lack of recognition of potential symptoms of malaria by both IDUs and health professionals, in conjunction with potential non-compliance with prophylactic and treatment regimens by IDUs, may contribute both to increased transmission probabilities as well as to evolution of drug-resistant strains of malaria. Finally, the co-existence of very high rates of HIV and malaria infection in developing countries, in conjunction with rapidly changing patterns of drug use, and specifically the self-administration of injecting drugs in a growing number of developing countries ${ }^{2,48}$ suggest that the potential for transmission of malaria infection through sharing of injection equipment, and for co-infection with malaria and HIV in IDUs, may soon become relevant to other developing countries besides Brazil. In addition, malaria is making a dramatic comeback worldwide due to increased travel and migration, and as such has been classified as an 'emerging infection' that could even intermittently affect some regions of developed countries. ${ }^{63}$

Migrant populations (and members of their social networks), IDUs and people living near malaria foci should be targeted by specific preventive programmes highlighting both HIV/ AIDS and malaria prevention, and enabling them to recognize malaria symptoms. Health education interventions should address the risks of primary malaria infection and the possibility of its secondary spread through the sharing of needles, syringes and other drug-injecting paraphernalia. Individuals need to be informed and empowered toward safe behaviours both concerning primary malaria infection and secondary malaria and/or HIV. Expanded access to sterile injection equipment through programmes of needle and syringe exchange and/or distribution, and programmes directed towards modification of drug injecting/sharing practices of individuals and their networks, have a critical role to play in 
the control of HIV infection and other bloodborne diseases, ${ }^{62,64}$ including secondary malaria.

Health professionals must also be alerted to the (until now, uncommon) possibility of HIV and malaria co-infection, when consulting an IDU with fever, malaise and related symptoms. The emergence of resistant strains of Plasmodium (especially $P$. falciparum) could be minimized by health programmes incorporating outreach components and directly observed therapies, as well as timely management of malaria relapses.

\section{Acknowledgements}

Drs Bastos and Barcellos are in receipt of salary grants from the Brazilian National Research Council (CNPq). Dr Bastos is a recipient of a Medical Research Council of Canada (CNPq) scholarship at Laval University.

\section{References}

1. Garfein, R.S., Vlahov, D., Galai, N., Doherty, M.C. \& Nelson, K.E. (1996) Viral infections in short-term injection drug users: the prevalence of the hepatitis C, hepatitis B, human immunodeficiency virus, and human $\mathrm{T}$ lymphotropic viruses, American fournal of Public Health, 86, 655-661.

2. Des Jarlais, D.C., Stimson, G., Hagan, H. et al. (1996) Emerging infectious diseases and the injection of illicit psychoactive drugs, Current Issues in Public Heath, 2, 1320-1327.

3. Rezza, G., Pizzuti, R., De Campora, E., De Masi, S. \& Vlahov, D. (1996) Tetanus and injections drug use: rediscovery of a neglected problem? European fournal of Epidemiology, 12, 655-656.

4. Amela, C., Lopez-Gay, D., Alberdi, J.C. \& Castilla, J. (1996) Injecting drug use as risk factor for visceral leishmaniasis in AIDS patients, European fournal of Epidemiology, 12, 91-92.

5. Bastos, F.I., Telles, P.R., Castilho, E.A. \& Barcellos, C. (1995) A epidemia de AIDS no Brasil [The AIDS epidemic in Brazil], in: Minayo, M.C.S. (Ed.) Os Muitos Brasis: Saúde e População na Década de 80, pp. 245-268 (São Paulo/Rio de Janeiro, Hucitec \& ABRASCO).

6. Lowndes, C.M., Reis, A.C.G.V., Bastos, F.I. \& D'Orsi, E. (1997) AIDS as a leading cause of mortality in young adults in two major Brazilian cities, Canadian fournal of Infectious Diseases 8(suppl. A), 40A.

7. Sabroza, P.C., Kawa, H. \& Campos, W.S.Q. (1995) Doenças transmissíveis: ainda um desafio [Communicable diseases: still a challenge], in: Minayo, M.C.S. (Ed.) Os Muitos Brasis: Saúde e População na Década de 80, pp. 245-268 (São Paulo/Rio de Janeiro, Hucitec \& ABRASCO).

8. Szwarcwald, C.L., Bastos, F.I., Viacava, F. \&
ANDRADE, C.L.T. (1999) Income inequality and homicide rates: a study in Rio de Janeiro, Brazil, American Fournal of Public Health, 89, 845-850.

9. Bastos, F.I. \& Barcellos, C. (1995) A geografia social da AIDS no Brasil [The social geography of AIDS in Brazil], Revista de Saúde Pública, 29, 52-62.

10. Barcellos, C. \& Bastos, F.I. (1996) Redes sociais e difusão da AIDS no Brasil [Social networks and the diffusion of AIDS in Brazil], Boletín de la Oficina Sanitaria Panamericana, 121, 11-24.

11. Szwarcwald, C.L., Bastos, F.I., Andrade, C.L.T. \& Castilho, E.A. (1997) AIDS: O mapa ecológico do Brasil, 1982-1994 [AIDS: the Brazilian ecological map], in: $A$ Epidemia de AIDS no Brasil: Situação e Tendências, pp. 27-44 (Brasília, Ministério da Saúde).

12. Szwarcwald, C.L. \& Bastos, F.I. (1998) Spatiotemporal model: an application to the AIDS epidemic in São Paulo, Brazil, in: GIERL, L., Cliff, A.D., Valleron, A.-J., Farrington, P. \& Bull, M. (Eds) Geomed '97, pp. 43-53 (Stuttgart/Leipzig, B.G. Teubner).

13. Bastos, F.I., Stimson, G., Telles, P.R. \& Barcellos, C. (1998) Cities responding to HIV1 epidemics among injecting drug users, in: STIMson, G., Des Jarlais, D.C. \& Ball, A. (Eds) Drug Injecting and HIV Infection: global dimensions and local responses, pp. 149-167 (London, UCL Press).

14. Szwarcwald, C.L., Bastos, F.I. \& Castilho, E.A. (1998) The dynamic of the AIDS epidemic in Brazil: a spatio-time analysis in the period 1987-1995, Brazilian fournal of Infectious Diseases, 2, 175-186.

15. Lima, E.S., Friedman, S.R., Bastos, F.I. et al. (1994) Risk factors for HIV infection among cocaine injectors in Rio de Janeiro, Brazil, Addiction, 89, 689-698.

16. Carvalho, H.B., Mesquita, F., Massad, E. et al. (1996) HIV and infections of similar transmission patterns in a drug injectors community of Santos, Brazil, fournal of Acquired Immune Deficiency Syndromes and Human Retrovirology, 12, 84-92.

17. Telles, P.R., Bastos, F.I., Guydish, J., Surrat, H., Pearl, M. \& Hearst, N. (1997) Risk behaviors and HIV seroprevalence among IDUs in Rio de Janeiro, Brazil, AIDS, 11(suppl. 1), S35-S44.

18. Brazilian Ministry of Health/National CoORdination ON STD/AIDS (1998) Boletim Epidemiológico-AIDS [Epidemiological Bulletin-AIDS], XI(1), December 1997/February 1998.

19. Arbex JR, J. (1993) Narcotráfico-Um fogo de Poder nas Américas [Drug Trafficking-a Game of Power in the Americas] (São Paulo, Editora Moderna).

20. Kalichman, A. (1993) AIDS and intravenousdrug use in Brasil, in: Monteiro, M.G. \& InCiARDI, J.A. (Eds) Brasil-United States Binational Research, pp.49-62 (São Paulo, CEBRID/ NIDA). 
21. Grangeiro, A. (1994) O perfil sócio-econômico da AIDS no Brasil [The socio-economic profile of AIDS in Brazil], in: PARker, R., Bastos, C., Galvão, J. \& Pedrosa, J.S. (Eds) A AIDS no Brasil, pp. 91-128 (Rio de Janeiro, ABIA/UERJ \& Relume-Dumará).

22. Oliveira, M.L.A, Bastos, F.I., Telles, R. et al. (1999) Prevalence and risk factors for HBV, $\mathrm{HCV}$ and HDV infections among injecting drug users from Rio de Janeiro, Brazil, Brazilian fournal of Medical and Biological Research, in press.

23. Kritsky, A., Carvalho, A.C.C., Schechter, M. et al. (1994) HIV-1, HTLV-1, and tuberculosis among intravenous drug users in Rio de Janeiro, Brazil. Poster (PC0278) presented at the $X$ International Conference on AIDS, Yokohama, Japan.

24. Andrade, T., Dourado, I. \& Galvão-Castro, B. (1998) Associations among HTLV-I/II and HIV in injecting drug users in Salvador, Brazil, Fournal of Acquired Immunodeficiency Syndromes and Human Retrovirology,18, 186-187 [letter].

25. WHO International Collaborative Group (1994) Multi-City Study on Drug Injecting and Risk of HIV infection (Geneva, WHO).

26. Goldberg, D.J., Frischer, M., TAylor, A. et al. (1994) Mobility of Scottish injecting drug users and risk of HIV infection, European fournal of Epidemiology, 10, 387-392.

27. Frischer, M. (1998) Mobility and the diffusion of drug injecting and HIV infection, in: STIMSON, G., Des Jarlais, D.C. \& Ball, A. (Eds) Drug Injecting and HIV Infection: global dimensions and local responses, pp.101-114 (London, UCL Press).

28. Telles, P.R. \& Bastos, F.I pelo Projeto Brasil (1995) O Contexto do uso de drogas em cinco cidades brasileiras [The injecting drug 'scene' in five Brazilian cities], Boletim ABIA, 27, 10-12.

29. Bastos, F.I. \& Coutinho, K. (1997) A epidemia pelo HIV/AIDS entre usuários de drogas injetáveis (UDI) no Brasil: Cenários [The Brazilian HIV/AIDS epidemic among IDUs: scenarios], in: A Epidemia de AIDS no Brasil: Situação e Tendências, pp. 71-86 (Brasília, Ministério da Saúde).

30. Souza, S.L., Noronha, C.V. \& Dourado, M.I. (1988) Migração e malária: um estudo casocontrole na área urbana de Camaçari, Bahia [Migration and malaria-results from a case-control study in Camaçari, Bahia, Brazil], Ciência \& Cultura, 40, 490-494.

31. Tauil, P.L. (1984) Malária: Agrava-se o quadro da doença no Brasil [Malaria: the Brazilian picture gets worse], Ciência Hoje, 2, 58-64.

32. SAwIER, D. (1993) Economic and social consequences of malaria in new colonization projects in Brazil, Social Science \& Medicine, 37, 1131-1136.

33. Marques, A.C. (1986) Migrations and the dissemination of Malaria in Brazil, Memórias do Instituto Oswaldo Cruz, 81(suppl. II), 17-30.

34. Duchiade, M.P. (1995) População brasileira: um retrato em movimento [Brazilian population: an evolving picture], in: Minayo, M.C.S. (Ed.)
Os Muitos Brasis: Saúde e População na Década de 80, pp. 14-56 (São Paulo/Rio de Janeiro, Hucitec \& ABRASCO).

35. Walsh, J.F., Molyneux, D.H. \& Birley, M.H. (1993) Deforestation: effects on vector-borne disease, Parasitology, 106, 555-575.

36. Castilla, R.E.F. \& Sawier, D.O. (1993) Malaria rates and fate: a socioeconomic study of malaria in Brazil, Social Science \& Medicine, 37, 1137-1145.

37. Ramos Filho, C. (1997) Unpublished report for the Rio de Janeiro's State Medical Council on 'Three Cases of $P$. vivax Malaria taking place in Rio de Janeiro State'.

38. MARINS, J. (1993) Malaria secondary to plasmaphereses in Rio de Janeiro. Unpublished medical doctoral thesis on infectious diseases. Federal University of Rio de Janeiro, Rio de Janeiro.

39. Biggam, A.G. (1929) Malignant malaria associated with the administration of heroin intravenously, Transactions of the Royal Society of Tropical Medicine and Hygiene, 23, 147-153.

40. Brecher, E.M. (1990) Needles and the conscience of a nation, in: Trebach, A.S. \& ZeEse, K.B. (Eds) Drug Prohibition and the Conscience of Nations, pp. 126-128 (Washington, The Drug Policy Foundation).

41. GeIGer, J.C. (1932) Malaria in narcotic addicts, fournal of the American Medical Association, 98, 1494.

42. Platt, J.J. \& Labate, C. (1976) Heroin Addiction (New York, John Wiley \& Sons).

43. Lo, S.S., Andrade, J.C.R., Condino, M.L.F., Alves, M.J.C.P., Semeghini, M.G. \& Galvão, E.C. (1991) Malária em usuários de drogas de administração endovenosa associada à soropositividade para HIV [Malaria among IDUs associated with HIV infection], Revista de Saúde Pública, 25, 17-22.

44. Barata, L.C.B., Andriguetti, M.T.M., CorTÁs, M.C. \& Meneguetti, C. (1990) Nota sobre surto de malária em usuários de drogas injetáveis [Research note about an outbreak of malaria among IDUs], Revista de Saúde Pública, 24, 321-322.

45. Barata, L.C.B., Andriguetti, M.T.M. \& Matos, M.R. (1993) Surto de malária induzida entre usuários de drogas injetáveis [An outbreak of secondary malaria among IDUs], Revista de Saúde Pública, 27, 9-14.

46. Wanderley, D.M.V., Silva, R.A. \& Andrade, J.C.R. (1994) Aspectos epidemiológicos da malária no estado de São Paulo, Brasil, 19831992 [Epidemiological aspects of malaria in São Paulo State, 1983-1992], Revista de Saúde Pública, 28, 192-197.

47. Domingues, C.S., Pellegrini, M., Cuncha, C. et al. (1998) Surveillance of the first case in Brazilian indian populations. Poster [23579] presented at the XII World AIDS Conference, Geneva, Switzerland.

48. Adelekan, M. \& Stimson, G. (1997) Problems and prospects of implementing harm reduction for HIV and injecting drug use in high risk sub- 
saharan African countries, fournal of Drug Issues, 27, 97-116.

49. Greenberg, A.E. (1992) HIV and Malaria, in: Mann, J., Tarantola, D. \& Netter, T. (Eds) AIDS in the World, pp. 143-147 (Cambridge, MA, Harvard University Press).

50. Same-Ekobo Lohoue, J. \& Monny-Lobe, M. (1994) Treatment of malaria in patients with AIDS, Revista da Sociedade Brasileira de Medicina Tropical, 27(suppl. IV), 25-26.

51. Wabwire-Mangen, F., Shiff, C.J., Vlahov, D. et al. (1989) Immunological effects of HIV-1 infection on the humoral response to malaria in an African population, American fournal of Tropical Medicine and Hygiene, 41, 504-511.

52. Niyongabo, T., Deloron, P., Aubry, P. et al. (1994) Prognostic indicators in adult cerebral malaria: a study in Burundi, an area on high prevalence of HIV infection, Acta Tropica, 56, 299-305.

53. Bloland, P.B., Wirima, J.J., Steketee, R.W., Chilima, B., Hightower, A. \& Breman, J.G. (1995) Maternal HIV infection and infant mortality in Malawi: evidence for increased mortality due to placental malaria infection, $A I D S$, 9, 721-726.

54. Chandramohan, D. \& Greenwood, B.M. (1998) Is there an interaction between human immunodeficiency virus and Plasmodium falciparum? International fournal of Epidemiology, 27, 296-301

55. Hoffman, I., Taylor, T.E. \& Jere, C. (1998) The association between Plasmodium falciparum malaria illness and HIV-1 RNA viral burden. Poster [13297] presented at the XII World AIDS Conference, Geneva, Switzerland.

56. NeIva, A. (1910) Ueber die Bildung einer chinin- resistenten Rasse des Malariaparasiten [Remarks on the appearance of a strain of quinine-resistant malaria parasites], Memórias do Instituto Oswaldo Cruz, 2, 131-140.

57. WERnSDORFER, W.H. (1991) The development and spread of drug-resistant malaria, Parasitology Today, 7, 297-303.

58. JAYAWARDENE, R. (1993) Illness perception: social cost and coping-strategies of malaria cases, Social Science \& Medicine, 37, 1169-1176.

59. Friedman, S.R., Stepherson, B., Woods, J., Des Jarlais, D.C. \& WARD, TP (1992) Society, drug injectors, and AIDS, fournal of Health Care for the Poor and Underserved, 3, 73-89.

60. Curtis, R., Friedman, S.R., Neaigus, A., Jose, B., Goldstein, M. \& Des Jarlais, D.C. (1993) Implications of directly observed therapy in tuberculosis control measures among IDUs, Public Health Reports, 109, 319-327.

61. Frieden, T.R., Sterling, T., Pablos-Mendez, A., Kilburn, J.O., Cauthen, G.M. \& Dooley, S.W. (1993) The emergence of drug-resistant tuberculosis in New York City, The New England Fournal of Medicine, 328, 521-526.

62. Friedman, S.R., Curtis, R., WARd, T.P. et al. (1995) Drogenabhängigkeit und Tuberkulose in den USA [Drug dependence and tuberculosis in the USA], in: Göltz, J. (Ed.) Der drogenabhängige Patient, pp. 229-236 (München, Urban und Schwarzenberg).

63. DAY, K.P. (1998) Malaria: a global threat. In: Krause, R.M. (Ed.) Emerging Infections, pp. 463-497 (San Diego, Academic Press).

64. Strathdee, A.S., Van Ameijden, E., Mesquita, F., Wodak, A., Rana, S. \& Vlahov, D. (1998) Can HIV epidemics among injection drug users be prevented? AIDS, 12(suppl. A), S71-S79. 